itself was that made by Larcum Kendall as a duplicate of the fourth instrument made by John Harrison. Known as "Mr. Kendall's Watch", this instrument received high praise from Cook and greatly facilitated the research of the astronomers aboard. The botenical and zoological records made by John Reinhold Forster and his son George, together with the anthropological and other observations of Cook and his companions, have now passed into the annals of the early scientific history of the Pacific.

This volume, like its predecessor (see Nature, 179 $390 ; 1957$ ), is a model of editing. In the introduction to his first volume Dr. Beaglehole rather prematurely stated that the study of Cook's journals is more complicated for the first voyage than for the second. In the introduction to this volume he remarks rather ruefully that the more the textual problem for this volume is scrutinized, the more complicated it becomes, since there is no existing original versionproperly speaking-of Cook's journal on the Resolution. The editor deserves, therefore, all the more congratulations for the meticulous way in which he has accomplished his task. The text primarily used for this volume is that of a holograph manuseript in the British Museum, written by Cook. This has been supplemented by material from another parallel manuscript, also by Cook, which he used as a draft for printing his own Voyage towards the South Pole, which appeared in 1777. Readers who have known the latter will recognize the great value of the present edition for the expansion of the text, and for the scholarly introduction and abundance of footnotes which assist a great deal in the interpretation. In addition, extracts from officers' records, including that of Furneaux; the journal of William Wales, the astronomer; papers from the Board of Longitude respecting instruments and their use; some letters by Cook; and an admirably annotated calendar of documents add much to the story of the voyage. Of particular human interest in the penumbra of scientific activity is the account of the abortive attempt by [Sir] Joseph Banks (afterwards president of the Royal Society) to assume a leading part in the voyage. In his introduction, Dr. Beaglehole seems to be rather hard on Banks. But his reproduction of Banks's own letter to the Earl of Sandwich, as First Lord of the Admiralty, makes it quite clear that Banks's concern for the size and accommodation of his own retinue weighed with him at that time more than a proper thought for the scientific objectives of the voyage. The volume is completed by an important series of maps and plans and many very effective illustrations, including a large number by Hodges, the official artist.

R. FIRTH

\section{FLORA OF NEW ZEALAND}

\section{Flora of New Zealand}

By H. H. Allan. Vol. 1: Indigenous Tracheophyta Psilopsida, Lycopsida, Filicopsida, Gymnospermae, Dicotyledones. Pp. liv + 1085. (Wellington: Government Printer, 1961.) 105s.

THE publication of a new Flora of New Zealand is an event of supreme importance, and the work now available is a remarkable tribute to the industry and critical botanical sense of the author. Unfortunately, Dr. Allan did not live to complete his formidable task of compilation and eluoidation, and this book, which includes all indigenous vascular plants except the monocotyledons, was most worthily finished and seen through the press by Miss Lucy B. Moore. It is thirty-six years since the last compre. hensive deseriptive account of New Zealand plants was published by F. T. Cheeseman, and in that period collectors and investigators have been most aetive in the study of the flora. Dr. Allan played a leading part in these researches and in field-work, and his wealth of knowledge of plants, botanical literature and the classic collections preserved in Britain equipped him admirably for the forbidding exercise of preparing a new Flora.

Students of the vegetation of New Zealand are well aware of the problems of unusual taxonomic complexity with which the flora of the country bristles. In many groups delimitation of acceptable taxa is notoriously difficult because of the high degree of polymorphy and the prevalence of natural hybridity. There is a wide range of habitats, and the comparatively small area of New Zealand has developed an extraordinary concentration of critical genera. Possibly, as has been suggested in the case of the northtemperate flora, some disturbance of the genetical balance during glacial periods has led to the intense and critical diversification which poses the multitude of taxonomic problems. Most informative, adequately referenced, supplementary notes throughout the work add greatly to its value and assist the reader to gain a better understanding of the many specific and generic complexities.

There is still ample scope for research, and Dr. Allan's work reveals most pertinently the many challenging features of the New Zealand flora. Within the compass of little more than a thousand pages he has produced a concise, convenient and eminently satisfactory Flora which will be of immense help in identifying New Zealand plants. Many beautiful New Zealand species have enriched gardens in other parts of the world, and horticulturists will certainly welcome this informative and valuable work.

There is an excellent ehronological bibliography and, throughout, copious references are given to relevant literature. This is a work thoroughly to be recommended to all interested in the New Zealand flora-indeed, it is an indispensable tool.

GEORGE TAyLOR

\section{SAMPLING AND ANALYSIS OF COMBUSTION PRODUCTS}

\section{Gas Sampling and Chemical Analysis in Combustion Processes}

By Prof. G. Tiné. (AGARDograph No. 47.) Pp. $x v+94$. (London and New York: Pergamon Press, 1961. Published for and on behalf of Advisory Group for Aeronantical Research and Development, North Atlantic Treaty Organization.) 42s. net.

WIIS latest AGARDograph is devoted to a review of the experimental technique which forms its title, with particular reference to combustion phenomena of aeronautical interest. A proper appreciation of this subject involves a full understanding of many aspects of chemistry, aerodynamics and heat transfer, and it is rare to find an author with an equally detailed acquaintance of all three branches of science. It is clear from the introduction (Section $A, 3$ pages) that Prof. Tine is well aware of the great importance of chemical phenomena in combustion processes. but 